\title{
Energy efficient of the production of the heat insulation based on the basalt super thin fibers
}

\author{
V.O. Kremnev (ORCID 0000-0003-4004-6671), L.U. Shpilberg (ORCID 0000-0002-8764-4786), \\ A.V. Timoshchenko (ORCID 0000-0001-6840-5491), O.V. Hylienko (ORCID 0000-0002-2220-3154), \\ Ye.V. Timoshchenko (ORCID 0000-0002-0012-2732)
}

Institute of Engineering Thermophysics of NAS of Ukraine, str. Bulakhovskogo, 2, Bldg. 2, Kyiv, 03164, Ukraine Tel.: $+380444243285,+380444241156$

E-mail: a_timoshchenko@ukr.net

Article info: received 09.12.2018, revised 15.12.2018, accepted 26.12.2018

Kremnev, V.O., Shpilberg, L.U., Timoshchenko, A.V., Hylienko, O.V., Timoshchenko, Ye.V. (2018) Energy efficient of the production of the heat insulation based on the basalt super thin fibers, 4(41), doi: 10.26909/csl.4.2018.3

A brief historical overview of the creation of technology of the materials based on staple basalt fibers is given. The primary role in creating the technology of the Institute for Problems of Materials Science of the National Academy of Sciences of Ukraine, a number of academic and sectoral institutes is noted. Thermophysical characteristics of basalt fibrous materials and basalt-bentonite products are given. For fibrous materials based on BSTF, the following dependences are given: thermal conductivity coefficient, as a function of density and temperature; optimal density of the heat insulating canvas, characterized by a minimum coefficient of thermal conductivity, as a function of temperature; the compaction factor of the canvas, as a function of temperature. The description of the multistage duplex process of the BSTF production is given. The block diagrams of the production processes for soft and semi-rigid products are considered. The stages of production at which natural gas is consumed are highlighted. A high proportion of the cost of energy in the cost of finished products reaches $70-80 \%$ is given. The results of experimental-industrial tests of the main gas-using equipment - melting furnaces, gas burners, tunnel dryer are given. Two methods were used to determine specific energy consumption. The maximum of the values determined by different methods was chosen as the defining value of energy consumption. There is a non-stationary nature of the equipment. The results of the analysis are presented in the form of specific indicators of natural gas consumption per unit of finished product, and heat per $1 \mathrm{~kg}$ of evaporated moisture. Thus, the specific consumption of natural gas per $1 \mathrm{~kg}$ of BSTF, for the existing technology, is 4,8 standard cubic meter, and the release of 1 cubic meters basalto-bentonite plate - 300 standard cubic meter. The basic heat engineering principles are formulated, which will allow a multiple increase in the energy efficiency of heat technologies, among them - the reduction of losses through the structures of equipment; loss reduction with high-temperature combustion products; intensification of heat and mass transfer processes in equipment components and elimination of unorganized gas exchange of internal technological volumes.

Key words: basalt fibers, basalt-bentonite products.

\section{Енергетична ефективність виробництва теплової ізоляції на основі базальтових супертонких волокон}

\author{
В.О. Кремньов, Л.Ю. Шпільберг, А.В. Тимощенко, О.В. Гулієнко, Є.В. Тимощенко
}

Інститут технічної теплофізики НАН Украӥни, Київ, Україна

Наводиться короткий історичний огляд створення технології матеріалів на основі штапельних базальтових волокон, теплофізичні характеристики матеріалів. Для волокнистих матеріалів на основі БСТВ наводиться залежність коефіцієнта теплопровідності від густини і температури. Розглянуто структурні схеми процесів виробництва м'яких і напівтвердих виробів. Відзначено високу частку вартості енергоносіїв в собівартості готової продукції. Наводяться результати дослідно-промислових випробувань основного обладнання, що використовує природний газ - ванних плавильних печей, камер роздування, тунельної сушильної установки. Результати ана- 
лізу представлені у вигляді питомих показників споживання природного газу на одиницю готової продукції, і теплоти на 1 кг випареної вологи. Сформульовано принципи, які дозволять кратно підвищити енергетичну ефективність теплотехнологій.

\section{Вступ}

Технологія виробництва базальтових супертонких волокон (БСТВ) та теплозвукоізоляційних виробів на їх основі була створена рядом установ Національної академії наук України у 70-х роках $\mathrm{XX}$ сторіччя. Чільне місце в цій розробці посідав Інститут проблем матеріалознавства НАН України, у складі якого існувала лабораторія базальтових волокон. Брали участь Інститути газу та технічної теплофізики НАН України, галузеві Інститути - склопластиків та волокна, та будівельних матеріалів і виробів. Основним користувачем продукції виступав військово-промисловий комплекс колишнього СРСР, зокрема військове суднобудування та авіаційна промисловість. Технологія вельми складна, а продукція і на сьогодні є неперевершеною за своїми показниками призначення. Створення відповідної підгалузі являло собою значуще науково-технічне досягнення української науки та промисловості. Були споруджені заводи в різних регіонах колишнього СРСР, які освоїли виробництво БСТВ та виробів на його основі, таких як, теплоізоляційне полотно, прошивні теплоізоляційні мати, шнури, прядені нитки та тканини на їх основі, теплоізоляційний картон, жорсткі теплоізоляційні плити та ін. На сьогодні Інститут проблем матеріалознавства продовжує роботу у цій галузі, зокрема щодо заміни платинородієвих фільєрних живильників, на фільєрні живильники з тугоплавких металосплавів.

Щодо наукових центрів, які проводять дослідження та розробки у напрямі виробництва БСТВ та теплозвукоізоляційних та композиційних матеріалів на їх основі, слід зазначити: в Україні Інститут проблем матеріалознавства НАН України i його спеціалізовану лабораторію базальтових волокон, Інститут склопластиків і волокна, ВКП «Чернівецький завод теплоізоляційних матеріалів». Останній зокрема брав участь сумісно з Інститутом проблем матеріалознавства у створенні виробництва у В'єтнамі.

В Росії - «НДІграфіт» за підтримки управління розвитку Генплану уряду Москви розробив і координує при виконанні «Комплексну програму по використанню нових базальтоволокнистих виробів у міському господарстві м. Москви («Базальт»)». Виконавцями програми є більше сорока науково-дослідних, проектних та промислових організацій м.
Москви і регіонів, виробники базальтової продукції ГУП «НДІграфіт», АТ «Судогомське скловолокно», АТ «Мостермоскло», НТЦ «Базальт».

В Канаді активні дослідження проводить науково-дослідний центр компанії «АЛБАРІ Канада Лімітед», який співпрацює з «НДІграфіт», Росія.

Одна з основних задач, яка стоїть перед виробниками БСТВ, що стримує розвиток галузі та освоєння нових ринків, та потребує вирішення, це зниження собівартості готової продукції.

Мета роботи полягає в визначенні величини питомого споживання природного газу на одиницю готової продукції в традиційних теплотехнологіях.

\section{Матеріали та методи дослідження}

Робота виконувалась 3 дотриманням наступної структури:

- проведено якісний аналіз теплотехнологій 3 виділенням основних операції;

- визначено операції, в яких споживаються енергоносії;

- для цих операцій визначено обладнання, що споживає природній газ та електричну енергію;

- проведено дослідно-промислові випробування обладнання, та обчислено питомі енергетичні показники на випуск одиниці продукції;

- зроблено висновки стосовно подальших шляхів вдосконалення теплотехнологій.

Характеристики деяких матеріалів та виробів 3 штапельного базальтового супертонкого волокна подаються в таблиці 1.

Теплоізоляція на основі базальтових супертонких волокон являє собою нетканий прошивний матеріал у вигляді полотна, який складається 3 сукупності штапельних базальтових скляних волокон довжиною від 10 до 100 мм. Крім волокнистих матеріалів на цій основі виробляються також вироби у вигляді плит різної товщини та жорсткості (від картонів товщиною 5-20 мм до плит товщиною 30-100 мм). В якості зв'язуючого в них використовується бентонітова глина.

Залежність коефіцієнту теплопровідності теплоізоляційного матеріалу на основі БСТВ (з середнім діаметром елементарних волокон 1,7 мкм), як функції від температури (діапазон від 25 до $300{ }^{\circ} \mathrm{C}$ ) та густини (діапазон від 20 до 100 кг/м³), одержаної шляхом апроксимації експериментальних даних поданих в роботі [2, табл. 10.13], описується формулою (1) та подається нижче (рис. 1). Крім того,

$$
\lambda=\left(9,71 \cdot 10^{-9} t+2,67 \cdot 10^{-6}\right) \rho^{2}-\left(2,40 \cdot 10^{-6} t+3,09 \cdot 10^{-4}\right) \rho+\left(2,62 \cdot 10^{-4} t+4,02 \cdot 10^{-2}\right) .
$$


на рисунку наводяться нормативні значення коефіцієнтів теплопровідності теплоізоляційних виробів на основі мінеральних (в тому числі базальтових) волокон (пунктирні криві) та крива мінімальних значень коефіцієнтів теплопровідності (чорна штрих-пунктирна крива).

Оптимальна густина теплоізоляційного матеріалу на основі БСТВ, яка характеризується мінімальними значеннями коефіцієнтів теплопровідності при різних температурах визначається за формулою (2):

$$
\rho=\frac{\left(2,40 \cdot 10^{-6} t+3,09 \cdot 10^{-4}\right)}{\left(1,94 \cdot 10^{-8} t+5,34 \cdot 10^{-6}\right)} .
$$

Залежність коефіцієнту ущільнення теплоізоляційного матеріалу $\left(K_{c}\right)$ від температури, що відповідає оптимальним теплозахисним властивостям теплоізоляційного шару, визначається як відношення оптимальної густини волокнистого матеріалу до густини неущільненого матеріалу [5], для техноло-

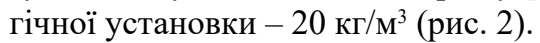

Сировиною для виробництва БСТВ є базальтова крихта з розмірами фракцій від 2 до 19 мм, яка добувається у кар'єрах, запаси в яких практично невичерпні. Україна має дуже сприятливі умови видобутку базальтової крихти, яка має оптимальний хімічний склад і не потребує шихтування [6]. Крихта дискретно-безперервно завантажується у базальтоплавильні печі, які обігріваються пальниками на природному газі. За допомогою печей вирішують наступні технологічні задачі [7 - 9]: розплавлення камінців базальту, тобто їх перехід
3 твердого стану до рідиноплинного; гомогенізація розплаву, яка полягає в усуненні 3 розплаву мікрокристалів і перетворення розплаву базальту на аморфну скловидну рідиноплинну масу. Це необхідно для того, щоб уникнути ламкості волокон, які при наявності мікрокристалів з'являються на подальших стадіях переробки. Гомогенізована скловидна маса самопливом переходить у так званий фідерний пристрій, що являє собою керамічну ємність 3 перфорованим днищем (так званим пластинчастим фільєрним живильником), який виготовляється чи 3 платинородію, чи зі спеціальних тугоплавких сплавів. Для запобігання охолодження скломаси пластинчастий живильник обігрівається електричним струмом. Через отвори в пластинчастому фільєрному живильнику гомогенізована скловидна маса надходить до навколишнього середовища, при цьому завдяки охолодженню утворюються тверді грубі волокна у вигляді циліндрів діаметром 80-400 мкм. Грубі волокна за допомогою валкового пристрою спрямовуються у зону дії плаского високотемпературного струменя продуктів згорання природного газу, який має швидкість $300 \mathrm{~m} / \mathrm{c}$. Під час взаємодії ансамблю грубих волокон 3 високотемпературним струменем має місце ïx повторне розплавлення та роздування на супертонкі волокна елементарним діаметром 1-3 мкм, які осаджуються із газового потоку на сітчастому фільтрі. На фільтрі формується шар супертонких волокон, який безперервно чи періодично знімається $з$ фільтра. Описана багатостадійна технологія одержання супертонких волокон носить назву

Таблиця 1.

Характеристики теплоізоляційних матеріалів на основі БСТВ [1]

\begin{tabular}{|c|c|c|c|c|}
\hline Виріб & $\begin{array}{c}\text { Густина } \rho, \\
\kappa \Gamma / \mathbf{M}^{3}\end{array}$ & $\begin{array}{c}\text { Теплопровідність } \lambda, \\
\text { Вт } /\left(\mathrm{M}^{*}{ }^{\circ} \mathrm{C}\right)\end{array}$ & $\begin{array}{l}\text { Масова теплоєм- } \\
\text { ність матеріалу } c_{p}\end{array}$ & Примітка \\
\hline Мати прошивні безобкладочні & $\begin{array}{l}\text { не більше } \\
45\end{array}$ & $0,0279+16,5 \cdot 10^{-5} t$ & 0,84 & $\begin{array}{c}\text { Температура } \\
\text { застосування } \\
t_{3} \leq 900{ }^{\circ} \mathrm{C}\end{array}$ \\
\hline $\begin{array}{l}\text { Мати прошивні в оболонці зі } \\
\text { склотканини, кремнеземної } \\
\text { тканини, сітки Манье }\end{array}$ & $\begin{array}{l}\text { не більше } \\
45\end{array}$ & $0,0279+16,5 \cdot 10^{-5} t$ & 0,84 & $t_{3} \leq 750^{\circ} \mathrm{C}$ \\
\hline Плити м’які теплоізоляційні & 140 & $0,0357+14,6 \cdot 10^{-5} t$ & 0,84 & $t_{3} \leq 900{ }^{\circ} \mathrm{C}$ \\
\hline Плити жорсткі теплоізоляційні & 270 & $0,0375+15,0 \cdot 10^{-5} t$ & 0,84 & $t_{3} \leq 900^{\circ} \mathrm{C}$ \\
\hline $\begin{array}{l}\text { Плити теплоізоляційні } \\
\text { базальтові }\end{array}$ & $150 \ldots 250$ & $0,0419+13,9 \cdot 10^{-5} t$ & 0,84 & $t_{3} \leq 900^{\circ} \mathrm{C}$ \\
\hline Картон ТК-1 & до 270 & $0,0375+15,03 \cdot 10^{-5} t$ & 0,84 & $t_{3} \leq 850{ }^{\circ} \mathrm{C}$ \\
\hline
\end{tabular}




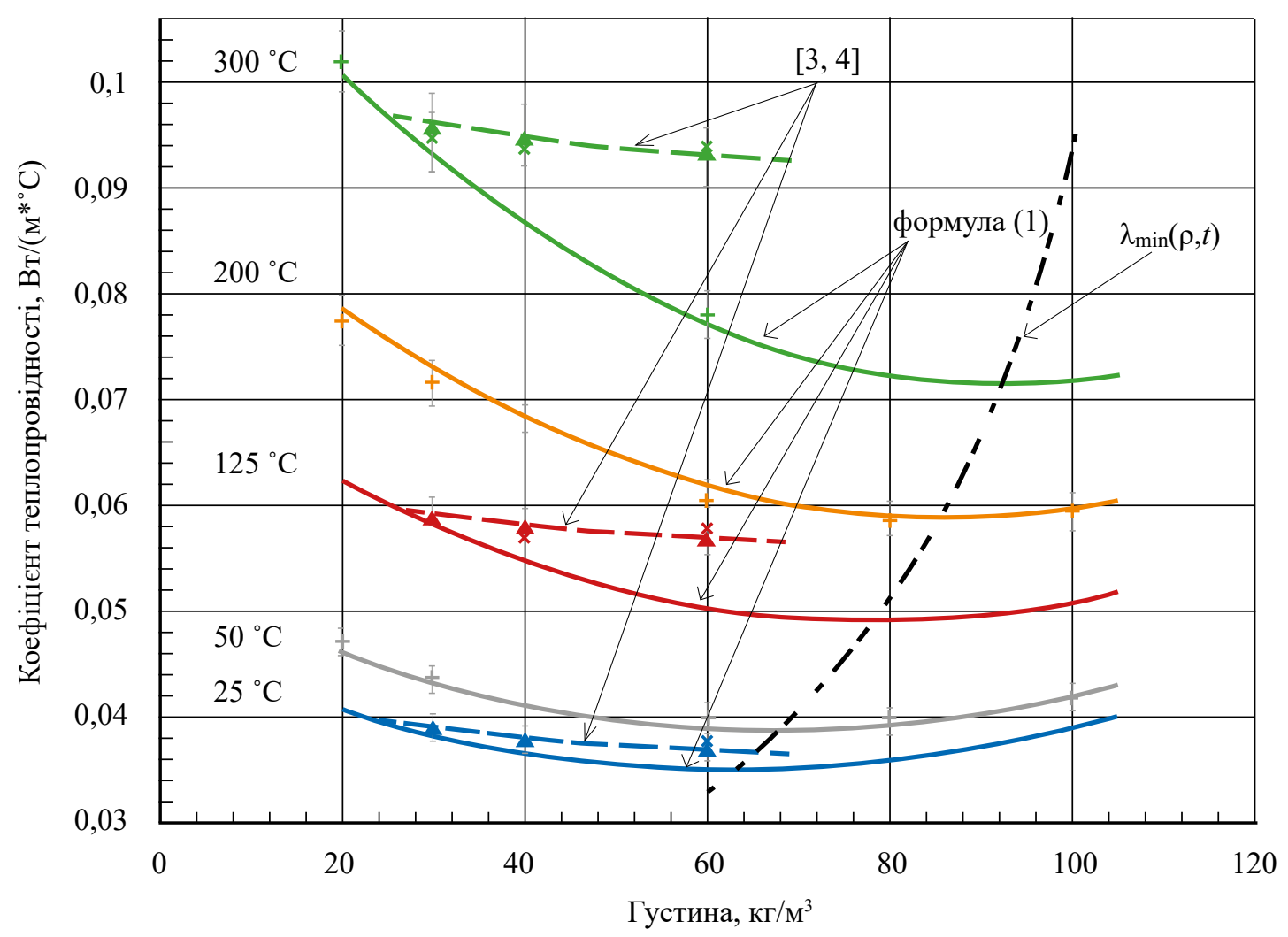

Рис. 1. Коефіцієнт теплопровідності теплоізоляційного матеріалу на основі БСТВ

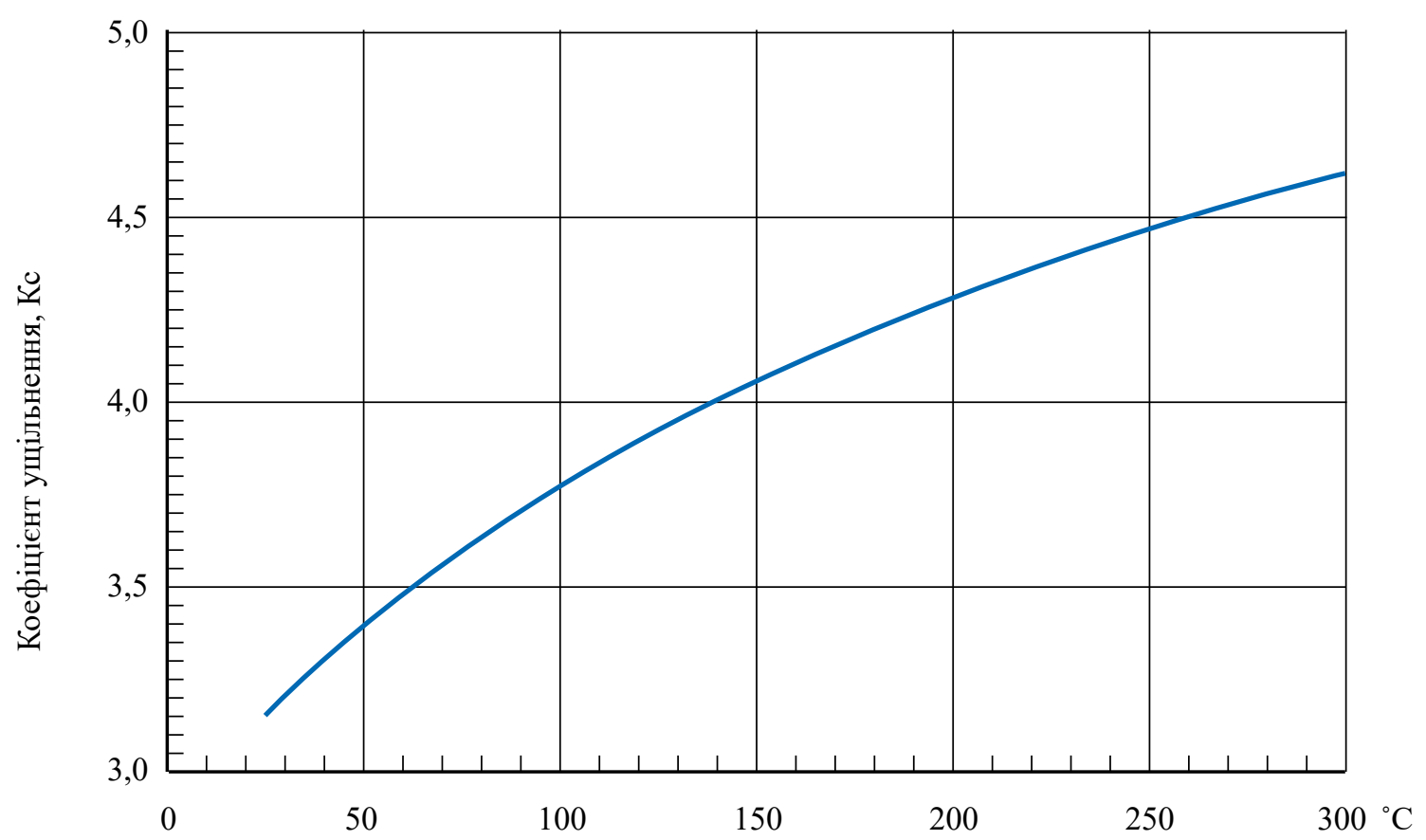

Рис. 2. Залежність коефіцієнту ущільнення від температури 
«дуплекс-процес». Ï̈̈ структурна схема наводиться на рис. 3 .

Кінцева обробка (сортування, сепарація, мийка) базальтової крихти до фракції $2 \div 19$ мм

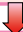

Транспортування та завантаження до газоопалювальної ванної базальтоплавильної печі

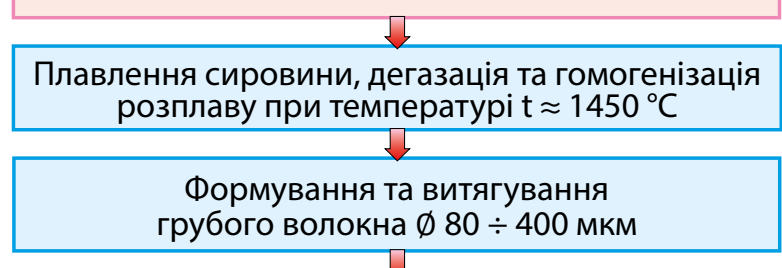

Повторне плавлення грубого волокна та його роздування в пласкій течії продуктів згоряння: $\mathrm{t} \approx 1600^{\circ} \mathrm{C}, \mathrm{w}=300 \mathrm{~m} / \mathrm{c}$, 3 одержанням штапельного волокна ф 1-3 мкм

Одержання штапельного волокна на сітчастому барабані з утворенням холсту 3 базальтового супертонкого волокна

\begin{tabular}{|c|c|}
\hline$\nabla$ & $\nabla$ \\
\hline $\begin{array}{l}\text { на виготовлення } \\
\text { «м 'яких» виробів }\end{array}$ & $\begin{array}{c}\text { на виготовлення «твердих» } \\
\text { базальто-бентонітових } \\
\text { виробів }\end{array}$ \\
\hline
\end{tabular}

Рис. 3. Багатостадійна технологія одержання БСТВ

Доведено, що саме супертонкі волокна, одержані у «дуплекс-процесі», забезпечують найкращі властивості теплозвукоізоляційних матеріалів. Це стосується пружності, опору тепловим витратам, строку експлуатації виробів. Із БСТВ виробляють, так звані, м'які вироби, такі, як холсти, прошивні мати, шнури, тканини, які використовуються як тепло-, звукоізоляційні та вогнезахисні матеріали. На основі БСТВ та бентонітового в'яжучого виробляють напівжорсткі та жорсткі вироби - картони та жорсткі плити, які мають широку номенклатуру використання. Структурна схема технології одержання базальто-бентонітових виробів наведена на рис. 4.

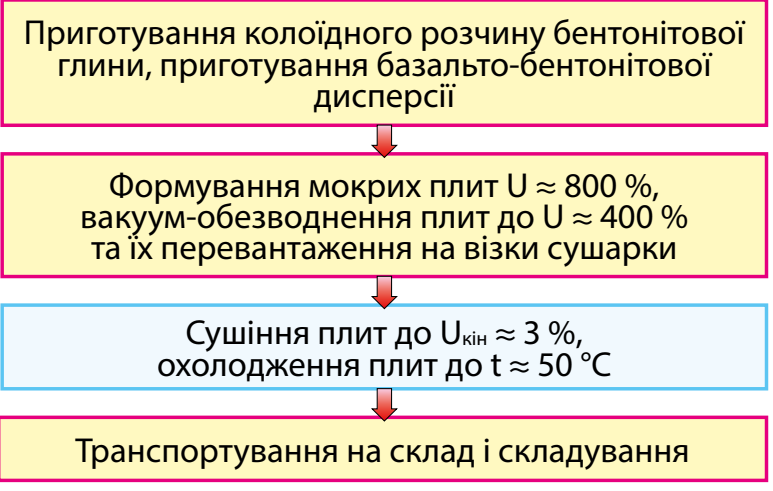

Рис. 4. Технологія одержання

базальто-бентонітових виробів
Головна проблема, яка стоїть перед галуззю, це швидке зростання собівартості виробництва БСТВ i, відповідно, виробів на його основі. Це зумовлено зростанням ціни, насамперед природного газу, який $є$ головним енергоносієм у цих виробництвах. На теперішній час витрати на природний газ досягають 70 - 80 \% від собівартості. Слід відзначити, що вчені і інженери, які створювали галузь не мали змоги застосовувати енергоефективні технічні рішення, через низьку ціну природного газу. Динаміка ціни на природний газ подається на рис. 5 [10]. Це призводило до того, що при виконанні техніко-економічного обгрунтування тих чи інших рішень, заходи, спрямовані на енергозбереження формально виявлялись збитковими, що унеможливлювало їх практичне застосування. Увага приділялась лише зниженню капітальних витрат через спрощення устаткування, зниження його матеріалоємності та підвищенню продуктивності. На сьогодні в галузі існує нагальна потреба технічного переоснащення спрямованого на докорінне зменшення питомих витрат природного газу.

\section{Результати та їх обговорення}

Дослідження проведено 3 метою визначення питомих витрат газу на окремих стадіях виробництва БСТВ та теплоізоляційних матеріалів на їх основі, при використанні існуючого (не модернізованого) заводського устаткування.

Дослідженню підлягали: а) піч для плавлення базальтової сировини; б) камера роздуву базальтових волокон; в) тунельна сушарка для базальто-бентонітових плит.

Витрати газу на кожен з видів устаткування визначалися шляхом проведення безпосередніх замірів, а також в результаті аналізу даних, зафіксованих в заводських журналах, по добовому споживанню газу і об’єму виготовленої продукції.

При проведенні вимірів витрати газу, в цеху працювало 5 печей і 3 камери роздуву. На печі плавлення базальту природний газ подається під абсолютним тиском 0,135 МПа; на камери для роздування ниток - під абсолютним тиском 0,15 МПа. Нижча робоча теплота згоряння природного газу становить

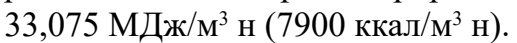

Витрати газу на 5 печей з урахуванням поправки на тиск склали 51,4 м³ н/год; витрати газу на 3 камери роздування $-62,1 \mathrm{~m}^{3} \mathrm{H} /$ год.

Виходячи 3 цих даних, середня витрата природного газу на одну піч плавлення базальтової крихти дорівнює $10,3 \mathrm{~m}^{3}$ н/год, а на одну камеру роздуву $20,7 \mathrm{M}^{3}$ н/год.

Розрахункова витрата природного газу на один встановлений на заводі модуль, що складається з 4-х 


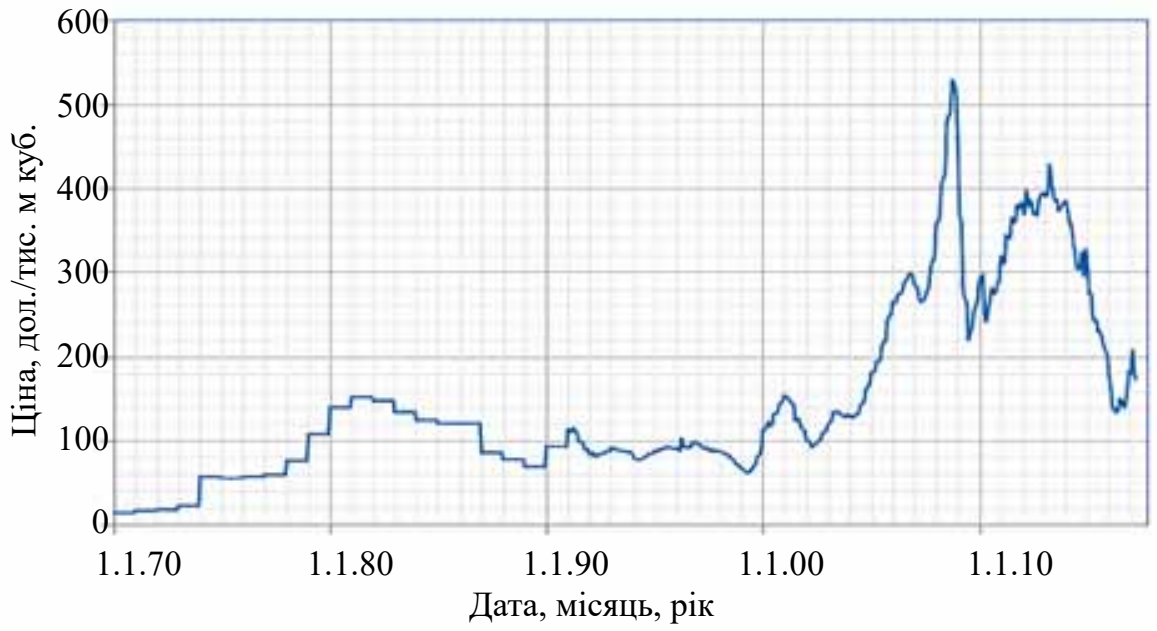

Рис. 5. Динаміка ціни природного газу за 1970-2017 рр.

печей і 2-х пальників для роздування, продуктивність якого 20 кг БСТВ/год, складає 82,6 м³ н/год.

Питомі витрати природного газу на 1 кг БСТВ складають:

- для базальтової печі - 2,06 м³ н/кг БСТВ;

- д для камери роздування - 2,07 м³ н/кг БСТВ.

Всього на процеси плавлення і роздування 1 кг БСТВ витрачається 4,13 м³ н природного газу.
Одержані вище значення питомого споживання природного газу перевіряються альтернативним методом. Метод грунтується на аналізі наявних в заводських журналах даних по споживанню природного газу та випуску готової продукції. Результати аналізу наводяться в зведеній таблиці 2.

Оцінка питомої витрати природного газу на сушіння теплоізоляційних базальтових плит грун-

Таблиця 2.

Питомі витрати газу на плавлення базальтової крихти, роздування волокон і сушіння теплоізоляційних плит

\begin{tabular}{|c|c|c|c|c|c|c|}
\hline День, місяць & $\begin{array}{c}\text { Витрата } \\
\text { газу на ду- } \\
\text { плекс-процес, } \\
\text { м³ н/доба }\end{array}$ & $\begin{array}{l}\text { Кількість } \\
\text { БСТВ, } \\
\text { кг/доба }\end{array}$ & $\begin{array}{c}\text { Питома витра- } \\
\text { та газу на ду- } \\
\text { плекс-процес, } \\
\text { м³ н/кг БСТВ }\end{array}$ & $\begin{array}{c}\text { Витрата } \\
\text { газу на су- } \\
\text { шіння, } \\
\text { м³ н/доба }\end{array}$ & $\begin{array}{l}\text { Кількість } \\
\text { плит, } \\
\text { м³/доба }\end{array}$ & $\begin{array}{c}\text { Питома витра- } \\
\text { та газу на су- } \\
\text { шіння плит, } \\
\text { м }^{3} \text { н / } \text { M }^{3}\end{array}$ \\
\hline 3 жовтня & 3651 & 835 & 4,4 & 1429 & 6,8 & 210,1 \\
\hline 4 жовтня & 3381 & 649 & 5,2 & 1666 & 10,08 & 165,3 \\
\hline 5 жовтня & 3262 & 721 & 4,5 & 1457 & 9,56 & 152,4 \\
\hline 6 жовтня & 0 & 0 & & 1667 & 4,04 & 412,6 \\
\hline 7 жовтня & 0 & 0 & & 3727 & 3,58 & 1041,1 \\
\hline 10 жовтня & 0 & 0 & & 2365 & 4,56 & 518,6 \\
\hline 12 жовтня & 3826 & 758 & 5,0 & 1420 & 8,35 & 170,1 \\
\hline 6 лютого & 2399 & 457 & 5,2 & 0 & 0 & \\
\hline 7 лютого & 2035 & 443 & 4,6 & 0 & 0 & \\
\hline 8 лютого & 2014 & 430,5 & 4,7 & 0 & 0 & \\
\hline 3 березня & 3348 & 638 & 5,2 & 0 & 0 & \\
\hline Разом & 23916 & 4931,5 & & 13731 & 46,97 & \\
\hline $\begin{array}{c}\text { Середній пито- } \\
\text { мий показник } \\
\text { за розглянутий } \\
\text { період }\end{array}$ & & & 4,8 & & & 292,3 \\
\hline
\end{tabular}


тується на аналізі заводських даних по витраті газу i випуску продукції. За даними заводу середнє споживання природного газу складало 130 тис. м ${ }^{3}$ н/період або $4300 \mathrm{~m}^{3}$ н/добу. Половина цієї кількості природного газу - 65 тис. $\mathrm{M}^{3} \mathrm{H} /$ період (2100 м 3 н/добу) - витрачається на сушіння базальтових плит.

Тривалість сушіння плит розміром $1 \times 1 \times 0,05$ м складає 18 годин. В середньому 4 пальники тунельної печі споживають разом на сушіння близько $2100 / 18=117$ м циклу сушіння плит товщиною 50 мм 3 урахуванням завантаження і вивантаження дорівнює 24 години. Продуктивність тунельної сушарки по готовій продукції (базальто-бентонітовим плитам) складає 7 м $^{3}$ плит/добу.

Використовуючи приведені вище усереднені статистичні дані, визначаємо питому витрату природного газу на сушіння $1 \mathrm{~m}^{3}$ базальто-бентонітових плит, іiі величина становить:

\section{$2100 \mathrm{M}^{3}$ н газу $/ 7 \mathrm{M}^{3}$ плит $=300 \mathrm{M}^{3}$ н газу $/ \mathrm{M}^{3}$ плит.}

Відформована мокра плита розмірами $1 \times 1 \times 0,05$ метрів разом з піддоном має масу 51 кг. Маса піддону - 19 кг. Таким чином, маса плити, що поступає в сушарку, складає 32 кг. Маса 4 висушених плит таких же розмірів складає 40 кг. Маса однієї сухої плити дорівнює 10 кг.

При сушінні однієї плити з неї видаляється приблизно 22 кг води. Щоб отримати $1 \mathrm{~m}^{3}$ сухих плит (20 шт.) треба видалити $22 \cdot 20=440$ кг вологи.

За заводськими даними вологовміст відформованих мокрих плит складає в середньому $300 \%$. Якщо виходити 3 цього вологовмісту, то при масі $1 \mathrm{~m}^{3}$ сухих плит 190 кг кількість вологи, що підлягає видаленню в сушарці, складає 570 кг. В якості розрахункової кількості вологи, що видаляється при сушінні $1 \mathrm{~m}^{3}$ плити, приймаємо середнє значення, що дорівнює 500 кг вологи/м ${ }^{3}$ плит. Всього в сушарці при сушіння плит товщиною 50 мм за цикл видаляється 500·7 = 3500 кг вологи.
При витраті газу на сушіння $1 \mathrm{M}^{3}$ базальтових плити питома витрата тепла на випаровування 1 кг вологи складає:

$q_{50}=\frac{300 \cdot 7900 \cdot 4,1868}{500}=19,845 \cdot 10^{3}$ кДж/кг вологи

3 цієї кількості теплоти безпосередньо на випаровування витрачається всього біля 2512 кДж/кг вологи. Решта тепла (приблизно 17,333·10³ кДж/кг) втрачається у довкілля через стінки сушарки; витрачається на нагрівання вагонеток і нагрівання плит; викидається в атмосферу разом 3 теплоносієм. Сюди слід віднести втрати, що пов'язані 3 негерметичністю установки, а також 3 хімічним недопалом газу.

При сушінні плит розмірами $1 \times 1 \times 0,1$ м тривалість процесу сушіння за заводськими даними складає 38 годин. Кількість висушуваної продукції при цьому складає 14 м $^{3}$. Всього вологи за цикл видаляється 7000 кг.

Треба відзначити, що в даному випадку тривалість процесу сушіння явно занижена, оскільки за цей час вологість плит не досягає необхідного значення і нерідко частина плит спрямовується на повторне сушіння. Для отримання продукції належної якості тривалість сушіння таких плит при підтримці прийнятої температури в сушарці повинна бути 48 - 54 год (у подальших розрахунках приймається 50 год). При цьому витрата теплоти на випаровування 1 кг вологи збільшується. При середній годинній витраті природного газу в 117 м³/год (як і у разі сушіння плит товщиною 50 мм), реальна питома витрата теплоти на випаровування вологи з плит завтовшки 100 мм складатиме:

$$
q_{100}=\frac{117 \cdot 7900 \cdot 50 \cdot 4,1868}{7000}=27,642 \cdot 10^{3} \text { кДж/кг }
$$

Дані по питомих витратах природного газу на виробництво БСТВ та базальто-бентонітових плит наводяться в таблиці 3 .

Таблиця 3.

Зведена таблиця питомих витрат природного газу на одиницю готової продукції

\begin{tabular}{|c|c|}
\hline Обладнання & Питома витрата природного газу \\
\hline Плавильна піч & $2,2 \mathrm{~m}^{3} \mathrm{H} /$ кг БСТВ \\
\hline Вузол роздування & $2,6 \mathrm{~m} \mathrm{~m}^{3} \mathrm{\kappa}$ БСТВ \\
\hline Сушарка (плити $\delta=50 \mathrm{Mм})$ & $300 \mathrm{~m}^{3} / \mathrm{m}^{3}$ плит \\
\hline
\end{tabular}


ISSN 2521-6694 (Print) Ceramics: science and life, 4(41), 2018

Таблиця 4.

Питомі витрати теплоти на випаровування 1 кг вологи

\begin{tabular}{|c|c|}
\hline Товщина плити, мм & $\begin{array}{c}\text { Питомі витрати тепла, МДж/кг вологи } \\
\text { (ккал/кг вологи) }\end{array}$ \\
\hline 50 & $19,845(4740)$ \\
\hline 100 & $27,642(6600)$ \\
\hline
\end{tabular}

Питомі витрати теплоти на випаровування 1 кг вологи залежно від товщини базальто-бентонітових теплоізоляційних плит приведені в таблиці 4.

\section{Висновки}

За сукупністю властивостей найбільш перспективною основою для теплоізоляційних матеріалів і виробів на їх основі є супертонкі базальтові волокна.

Існуючі теплотехнології, маючи за основну перевагу простоту конструкції обладнання, характеризуються низькою енергетичною ефективністю, ККД при використанні енергії для виробництва продукції не перевищує 4 \%.

Застосування базових теплотехнічних принципів при вдосконаленні технологій (таких як: зниження втрат через огороджуючи конструкції агрегатів; зниження втрат з високотемпературними продуктами згоряння; інтенсифікація тепломасообмінних процесів в елементах обладнання та усунення некерованого газообміну внутрішніх технологічних об'ємів) дозволяє розраховувати на кратне - більше ніж в 2 рази - зниження споживання природного газу на випуск готової продукції.

Кратне зниження долі енергоносіїв в собівартості якісної вітчизняної базальтової теплоізоляції складає основу для іiі широкого застосування в промисловому та цивільному будівництві.

\section{References}

1. Information on http://rotys.com/.

2. Джигирис, Д.Д., Махова, М.Ф. Основы произ- водства базальтовых волокон и изделий. - Теплоэнергетик, Москва. - 2002. - 416 с.

3. ДСТУ Б В.2.7-317:2016 Мати та шнури мінераловатні теплоізоляційні. Технічні умови. Національний стандарт України. - Київ: ДП «УкрНДНЦ». 2017. -23 c.

4. ТУ У В.2.7-23.9-00292818-001:2012 Маты прошивные безобкладочные МТПБа.

5. СНиП 2.04.14-88*. Тепловая изоляция оборудования и трубопроводов. Госстрой России. М.: ЦИТП Госстроя СССР. - 1998. - 28 с.

6. Минерально-сырьевая база горных пород Украины для производства волокон. Аналитический обзор. В.И. Трефилов, М.Ф. Махова, Д.Д. Джигирис [и др.] Промышленность строительных материалов. Серия 6. Промышленность полимерных, мягких кровельных и теплоизоляционных строительных материалов. - 1992, Выпуск 2. - 88 с.

7. Полевой, П.П. Теплообменные процессы при получении волокна раздувом минеральных нитей высокотемпературными газовыми потоками [Текст]. Дисс. канд. техн. наук: 05.14.04. Полевой Петр Петрович. - Киев. - 1982. - 193 с.

8. Татаринцева, О.С. Изоляционные материалы из базальтовых волокон, полученных индукционным способом [Текст]. Автореф. дисс. докт. техн. наук. Томск. $-2006 .-42 \mathrm{c}$.

9. Аблесимов, Н.Е., Земиов, А.Н. Релаксационные эффекты в неравновесных конденсированных системах. Базальты: от извержения до волокна. - Москва. $-2010 .-400$ с.

10. Information on https:/www.calc.ru/dinamikaGas.html. 